\title{
VARIABILITY OF THE INCIDENCE OF Fusarium SPECIES AND MYCOTOXINS IN THE GRAIN OF WHEAT, DEPENDING ON SOIL TILLAGE SYSTEM AND CULTIVAR
}

\section{ZMIENNOŚĆ WYSTĘPOWANIA GRZYBÓW Z RODZAJU Fusarium I MIKOTOKSYN W ZIARNIE PSZENICY, W ZALEŻNOŚCI OD SYSTEMU UPRAWY ROLI I ODMIANY}

Department of Weed Science and Tillage Systems, Institute of Soil Science and Plant Cultivation, State Research Institute, Wrocław, Poland

${ }^{1}$ Department of Plant Protection, Wrocław University of Environmental and Life Sciences, Poland

\begin{abstract}
Streszczenie. Celem pracy była analiza zmienności liczebności wybranych gatunków grzybów z rodzaju Fusarium i mikotoksyn w ziarnie pszenicy, w zależności od odmiany i systemu uprawy roli. Badano czynnik I, który stanowiły systemy uprawy roli: a) uprawa tradycyjna, b) uprawa bezorkowa wykonana kultywatorem, c) uprawa bezorkowa wykonana broną talerzową (tab. 1); czynnik II, który stanowiły odmiany pszenicy ozimej: a) 'Muszelka', b) 'Ostka Strzelecka', c) 'Kohelia' d) 'Satyna'. Odmiany pszenicy ozimej w warunkach upraw bezpłużnych odznaczały się większą liczebnością gatunków Fusarium niż na poletkach z konwencjonalnym systemem uprawy. Uprawa kultywatorem, w odniesieniu do wariantu uproszczonego z użyciem brony talerzowej, przyczyniła się do wzrostu populacji grzybów. Ziarno badanych odmian w uprawie płużnej nie wykazywało znacznych ilości badanych mikotoksyn. Natomiast, pomimo jednorocznej przerwy w uprawie zbóż, stwierdzono znaczne przekroczenia wartości granicznych zearalenonu ustalonych przez Unię Europejską dla upraw bezpłużnych. W warunkach uprawy uproszczonej broną talerzową odmiana 'Satyna' wykazywała duże skażenie ziarna deoksyniwalenolem. Znaczne ilości deoksyniwalenolu wykryto również w ziarnie odmiany 'Kohelia' na poletkach uprawianych kultywatorem. Analizując zawartość zearalenonu w uprawach bezpłużnych, wykazano kilkukrotne przekroczenie wartości granicznych, szczególnie w przypadku ziarna odmian 'Kohelia' i 'Satyna'. Natomiast odmiany 'Muszelka' i ‘Ostka Strzelecka' odznaczały się mniejszym skażeniem ziarna.
\end{abstract}

Key words: tillage systems, wheat cultivars, mycotoxin, log-linear analysis, correspondence analysis.

Słowa kluczowe: systemy uprawy, odmiany pszenicy, mikotoksyny, analiza log-liniowa, analiza korespondencji.

\section{INTRODUCTION}

Resistant cultivars are the most effective tool to reduce the yield loss and grain contamination with mycotoxins caused by Fusarium head blight (further abbreviated as FHB) on wheat. The FHB resistance genes used in breeding programs worldwide are most often

Corresponding author - Adres do korespondencji: Ryszard Weber, Department of Weed Science and Tillage Systems, Institute of Soil Science and Plant Cultivation, State Research Institute, Orzechowa 61, 50-540 Wrocław, Poland, e-mail: rweber@iung.pulawy.pl 
those found in Chinese cultivar 'Sumai 3' or in cultivars 'Wangshuiba'i, 'Wuhan' or 'Nyubai'. Unfortunately, in the conditions of the temperate climate 'Sumai 3' is characterized by its high susceptibility to powdery mildew and cereal rusts (Miedaner 2012). Although Góral (2006) had found no specific resistance to particular species of Fusarium, yet the later work of Weber and Kita (2010) demonstrated significant variation in the incidence of $F$. culmorum and $F$. avenaceum on the stem base of some wheat cultivars. Goliński et al. (1999) had found that the cultivars Aleta, Almari and Begra were resistant to FHB caused by $F$. avenaceum. An enhanced resistance to this disease was also found in the old cultivars such as 'Kujawska', 'Ostka Kazimierska', 'Mironowska 808' and 'Jubilatka' (Góral 2005). At present, the most frequently recorded species of the fungus in Europe include F. culmorum (W.G.Sm) Sacc., Gibberella zeae (Schwein.) Petch, Gibberella avenacea R.J. Cook , F. poae (Peck.) Wollenw. Monographella nivalis (Schaffnit) E. Müll. (Doohan et al. 2003).

A considerable genetic variation between the isolates of Fusarium fungi makes the resistance of their host plants dependent, to a large extent, on the environmental conditions (Rudd et al. 2001). Variable degree of correlation had been demonstrated between the symptoms of Fusarium head blight and DON concentration in grain ( $r=0.78$ in Lemmens et al. 1997, $r=0.5$ in Salas et al. 1999, $r=0.88$ in Miedaner 2012). Research carried out on different species of wheat (Triticum aestivum subsp. aestivum, $T$. aestivum subsp. spelta, T. turgidum subsp. dicoccon, T. monococcum subsp. monococum) shows distinguishable intraspecies variation in the level of FHB infestation (Oliver et al. 2008; Góral et al. 2012). The resistance of wheat to $F$. culmorum or $F$. graminearum is inherited in the polygenic manner, with majority of the genes responsible acting in the additive mode. Application of molecular markers allowed to determine that the largest effect on the wheat resistance to Fusarium head blight is exerted by the genes located on 3BS chromosome of this plant species (Buerstmayr et al. 2002). Based on their own research and on the available literature Buerstmayr et al. (2009) had found that on each chromosome of wheat, except for the 7D, quantitative trait loci (QTL) were discovered which determine resistance to FHB. This is therefore why the effect of genetic background may contribute, in particular breeding programs, to enhancement or reduction of resistance of wheat breeding lines to FHB. For the undesired effects of crossbreeding between the European forms and Chinese genotypes, most breeders search for alternative resistance sources.

Resistance genes have been fund in cv. 'Frontana' (brasilian wheat cultivar) and cv. 'Timgalen' (australian cultivar). Genes for resistance had been found in Canadian wheat cultivars of 'Frontana' and 'Timgalen'. In Timgalen, resistance QTL was found on chromosome 1B, 2B, 3A, 6A, 7A and 7D (Srinivasachary Gosman et al. 2009). Regrettably, a segment of 2B chromosome originates in $T$. timopheevii and as such it negatively affects the efficiency of selection for positive recombinants (Srinivasachary Gosman et al. 2009). Soil tillage system is one of the crucial factors capable of reducing the incidence of Fusarium diseases. However, the efficacy of this factor is dependent on the type of crop rotation and on the forecrop used in a particular field (Baert et al. 2006; Weber and Kita 2014). The non-ploughing (NP) soil tillage variants, that are particularly recommended for the regions exposed to water or wind erosion, may badly enhance the incidence of fungal diseases. It has been stressed in majority of published papers that the NP systems contribute to an increased incidence of Fusarium pathogens in wheat cultures. On the other hand, a number of other reports 
evidence no apparent effect of the soil tillage system on the wheat infections by Fusarium spp. fungi (Suproniene et al. 2012). Fungicides reduce the infection rate (on average) from $50 \%$ to $70 \%$ and reduce mycotoxin contamination levels from $50 \%$ to $80 \%$. It should be noted, however, that such effectiveness can only be achieved with the application of fungicide during the period of infection of the plants by the fungi. The treatment should be carried out at the beginning of flowering period (BBCH 61-63). Unfortunately, the farmer has only one or two days to achieve full effectiveness of the chemical substance. In practice, fungicides to combat diseases caused by Fusarium spp. are not very effective, due to inappropriate periods of use. That is why the variability of the fungus Fusarium was researched under conditions of active plant protection.

Consequently, the aim of the presented work was to analyse the variability of the incidence of selected Fusarium species and their mycotoxins in the grain of wheat, and their dependence on the wheat cultivar and on the soil tillage system.

\section{MATERIAL AND METHODS}

The study was carried out in 2012-2014 within the Jelcz-Laskowice district of Dolnośląskie voyvodeship (Lower Silesia, Poland) - Table 1. Two-factor experiment in split-plot design with four replicates was set after oilseed rape forecrop. The plot size for harvest was $110 \mathrm{~m}^{2}$.

Table 1. Soil tillage systems

Tabela 1 . Systemy uprawy

\begin{tabular}{|c|c|c|}
\hline $\begin{array}{l}\text { Soil tillage system } \\
\text { Systemy uprawy }\end{array}$ & $\begin{array}{c}\text { Abbreviation } \\
\text { Skrót }\end{array}$ & $\begin{array}{l}\text { Cultivation treatments } \\
\text { Zabiegi uprawowe }\end{array}$ \\
\hline $\begin{array}{l}\text { Conventional (ploughing) } \\
\text { Uprawa konwencjonalna } \\
\text { (płużna) }\end{array}$ & Conv. & $\begin{array}{l}\text { post-harvest tillage: gruber tillage unit at } 15 \mathrm{~cm}+\text { cage roller; main } \\
\text { tillage: ploughing at } 25 \mathrm{~cm}+\text { harrow; pre-planting tillage: combined } \\
\text { tillage unit (cultivator + cage roller) } \\
\text { uprawa pożniwna: gruber na głębokość } 15 \mathrm{~cm}+\text { wał strunowy; } \\
\text { uprawa podstawowa: orka pługiem } 25 \mathrm{~cm}+\text { brona; uprawa przed- } \\
\text { siewna: kultywator + wał strunowy }\end{array}$ \\
\hline $\begin{array}{l}\text { Reduced (non-plouging) } \\
\text { system using disc harrow } \\
\text { Uprawa uproszczona - } \\
\text { brona talerzowa }\end{array}$ & $\mathrm{NP} / \mathrm{dh}$ & $\begin{array}{l}\text { post-harvest tillage - disc harrow at } 15 \mathrm{~cm} \text {; pre-planting tillage - } \\
\text { combined tillage unit (cultivator + cage roller) } \\
\text { uprawa pożniwna: brona talerzowa głebokość } 15 \mathrm{~cm} \text {; uprawa przed- } \\
\text { siewna: kultywator + wał strunowy }\end{array}$ \\
\hline $\begin{array}{l}\text { Reduced (non-plouging) } \\
\text { system using cultivator } \\
\text { Uprawa uproszczona - } \\
\text { kultywator }\end{array}$ & $\mathrm{NP} / \mathrm{c}$ & $\begin{array}{l}\text { post-harvest cultivation - gruber tillage unit at } 10 \mathrm{~cm} \text {; pre-planting } \\
\text { tillage - combined tillage unit (cultivator + cage roller) } \\
\text { uprawa pożniwna: gruber na głębokość } 10 \mathrm{~cm} \text {; uprawa przedsiewna: } \\
\text { kultywator + wał strunowy }\end{array}$ \\
\hline
\end{tabular}

The experimental factors were as follows:

I. Soil tillage system: conventional system (Conv.), two non-ploughing (NP) systems, one of them using disc harrow (NP/dh), the other one using cultivator (NP/c) - Table1.

II. Winter wheat cultivars ('Muszelka', 'Ostka Strzelecka', 'Kohelia and Satyna') .

The wheat cultivars used varied considerably in the technological value of their grain; all four of them were frequently grown in Lower Silesia. At the beginning of anthesis (BBCH 61-63) Alert 375 SE fungicide (a.i: flusilazole, carbendazim) was applied to the experimental plots.

The aforementioned fungicide presents prominent effectiveness in limiting the growth of Fusarium spp. in laboratory conditions (Perek and Świerczyńska 2012). The mycological analysis was performed on the grain, sampled at full maturity of winter wheat immediately 
after harvest using combine harvester. Grain moisture content at this time was $<12 \%$. 30 ears were collected from every plot for analysis In each year of the study 300 grains per experimental variant were taken for the analysis. The seeds were disinfected for $2.5 \mathrm{~min}$. in $1.0 \%$ sodium hypochlorite. The excess of disinfectant was removed by the sterile blotting paper. Thus prepared grains were placed individually onto petri dishes with PDA medium acidified with citric acid to $\mathrm{pH}=5.5$, and incubated in thermostatic chamber at $23^{\circ} \mathrm{C}$ for 7-10 days. The fungal colonies that were appearing in the petri dishes were re-planted onto PDA slants and identified taxonomically according to the available identification keys (Booth 1971; Nelson et al. 1983).

Content of deoxynivalenol (DON), nivalenol (NIV) and zearalenon (ZEN) in the grain of the tested wheat cultivars was assessed using high performance liquid chromatography (HPLC) coupled with spectrophotometric detector in UV (Sadowski et al. 2010).

Many of biological phenomena have qualitative characteristics. At such instances, a typical analysis of variance designed for quantitative variables can be irrelevant. Results of such an analysis may contain an error resulting from transformation of the original values, e.g. numbers of colonies of particular fungal species, into variables of qualitative character. The method most frequently used in biological sciences in order to detect the effects of multiple factors on a variable of the qualitative-type is the log-linear analysis. It has been presented by Goodman (1971). In this type of analysis, significant deviations of the observed values from the expected ones point to an interaction between the analysed variables. After the logarythmic transformation of the expected values the model assumes linear form, which, in the simplest case, can be represented by the formula below:

$$
\operatorname{Ln}\left(E_{\mathrm{ij}}\right)=M+\lambda_{\mathrm{i}}^{\mathrm{X}}+\lambda_{\mathrm{j}}^{\mathrm{Y}}+\lambda_{\mathrm{ij}}^{\mathrm{XY}}
$$

where:

$E_{\mathrm{ij}}$ - stands for the expected values,

$M$ - general mean based on equal frequencies in each cell,

$\lambda_{\mathrm{i}}{ }^{\mathrm{X}}$ - stands for the effect of the $i^{\text {th }}$ value of the variable $X$,

$\lambda_{j}^{Y}$ - stands for the effect of the $j^{\text {th }}$ value of the variable $Y$,

$\lambda_{\mathrm{ij}}^{\mathrm{XY}}$ - may be described as the effect of interaction between the $i^{\text {th }}$ value of the variable $X$ and the $j^{\text {th }}$ value of the variable $Y$.

The log-linear model allows for verification on the null hypothesis (the one assuming no interaction between two or more of the analysed variables). After rejecting of the interactions that proved insignificant, it also makes it possible to assess the effect of particular factors on the variability of the population in question.

The associations, between the frequencies of selected fungal species of Fusarium genus on wheat grain and the soil tillage system, were assessed using the log-linear analysis described above. In order to analyse the frequency variability of particular isolate of Fusarium spp., depending on wheat cultivar and soil tillage system, the correspondence analysis (CA) was used. Canonical CA enables the assessment of the structure of cultivar dependence on the other experimental factors. The analysis represents cultivars in two-dimensional graph, in such a manner that a maximum supply of cultivar variability is conserved from the original, 15-dimensional (3 tillage systems $\times 5$ species of pathogens) coordinate system. Diversified weather conditions contributed to differences in the level of Fusarium infection. In the first 
experimental year Fusarium fungi occurred in high intensity, whereas in the subsequent years it appeared sporadically. For this reason, log-linear analysis was performed using mean values for 3-years period (Table 2).

Table 2. Average monthly and yearly air temperatures $(T)$ and monthly and yearly sums of rainfall $(O)$ in Jelcz Laskowice

Tabela 2. Średnia miesięczna i roczna temperatura powietrza $(T)$ oraz miesięczne i roczne sumy opadów deszczu (O) w Jelczu-Laskowicach

\begin{tabular}{|c|c|c|c|c|c|c|c|c|c|c|c|c|c|}
\hline \multirow{2}{*}{$\begin{array}{l}\text { Year } \\
\text { Rok }\end{array}$} & \multicolumn{12}{|c|}{ Month - Miesiące } & \multirow{2}{*}{$\begin{array}{c}\text { Yearly value } \\
\text { Średnia }\end{array}$} \\
\hline & I & II & III & IV & V & VI & VII & VIII & IX & $x$ & $X I$ & XII & \\
\hline \multicolumn{14}{|l|}{2012} \\
\hline $\mathrm{T}$ & -2.1 & -0.5 & -1.4 & 8.7 & 14.1 & 17.3 & 20.2 & 18.4 & 12.2 & 9.9 & 4.8 & 2.1 & 8.7 \\
\hline $\mathrm{O}$ & 53.8 & 31.2 & 41.0 & 39.3 & 115.5 & 153.2 & 30.3 & 49.0 & 110.2 & 8.7 & 23.5 & 14.3 & 670.0 \\
\hline \multicolumn{14}{|l|}{2013} \\
\hline $\mathrm{T}$ & 0.1 & -4.9 & 5.2 & 9.3 & 15.2 & 17.1 & 19.7 & 19.0 & 14.2 & 8.0 & 4.9 & -1.6 & 8.9 \\
\hline $\mathrm{O}$ & 61.2 & 38.5 & 16.3 & 22.4 & 25.3 & 92.2 & 88.4 & 78.2 & 50.1 & 55.8 & 26.1 & 24.9 & 579.4 \\
\hline \multicolumn{14}{|c|}{ 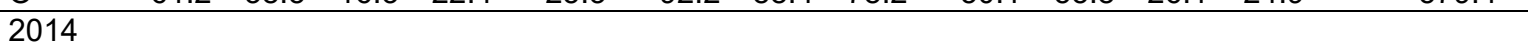 } \\
\hline $\mathrm{T}$ & 0.4 & 3.6 & 6.4 & 10.1 & 13.3 & 16.5 & 20.9 & 17.2 & 14.8 & 9.9 & 6.2 & 1.7 & 10.1 \\
\hline $\mathrm{O}$ & 46.5 & 2.2 & 34.4 & 34.6 & 82.2 & 47.3 & 92.5 & 74.4 & 89.1 & 60.1 & 12.7 & 22.6 & 598.6 \\
\hline
\end{tabular}

$\mathrm{T}$ - temperature - temperatura $\left[{ }^{\circ} \mathrm{C}\right], \mathrm{O}$ - rainfall - opady $[\mathrm{mm}]$.

\section{RESULTS}

Considerable frequencies of the following fungi of Fusarium spp. were detected on the grain of wheat: F. avenaceum (Corda ex Fr.) Sacc., F. culmorum (W.G. Smith) Sacc., F. graminearum Schwabe, F. poae (Peck Wollenw.), and F. tricinctum (Corda). The grain of the wheat cultivars was also infested to a significant degree, and irrespectively of the soil tillage system applied, by other species of pathogens, such as Alternaria alternata (Fr.) Geissler, Epicoccum purpurascens Ehrenb. ex Schlecht, Penicillium notatum Westling, and Sclerotinia sclerotiorum (Lib.) de Bary. Some other species like Ulocladium botrytis Preuss, Trichoderma harzianum Rifai, T. viridae Pers. ex S.F. Gray, Fusarium equiseti (Corda) Sacc. and Trichothecium roseum Link ex Fr., were present on the grain to a lesser extent.

Table 3. Tests of main effects, marginal and partial associations and interactions between experiment factors

Tabela 3. Testy związku brzegowego i związku cząstkowego oraz interakcje między badanymi czynnikami

\begin{tabular}{lccccc}
\hline \multicolumn{1}{c}{$\begin{array}{c}\text { Effect } \\
\text { Efekt }\end{array}$} & $\begin{array}{c}\text { Degrees } \\
\text { of freedom } \\
\text { Liczba } \\
\text { stopni } \\
\text { swobody }\end{array}$ & $\begin{array}{c}\text { Chi }^{2} \\
\text { partial } \\
\text { association } \\
\text { Związek } \\
\text { Cząstkowy }\end{array}$ & $\begin{array}{c}\text { Significance level } \\
\text { Poziom istotności } \\
(\mathrm{p})\end{array}$ & $\begin{array}{c}\text { Chi }^{2} \\
\text { marginal } \\
\text { association } \\
\text { Związek } \\
\text { brzegowy }\end{array}$ & $\begin{array}{c}\text { Significance level } \\
\text { Poziom istotności } \\
(\mathrm{p})\end{array}$ \\
\hline $\begin{array}{l}\text { Tillage system } \\
\text { System uprawy (1) }\end{array}$ & 2 & 30.03 & $<0.001$ & 30.03 & $<0.001$ \\
\hline $\begin{array}{l}\text { Cultivars } \\
\text { Odmiany (2) }\end{array}$ & 3 & 16.40 & $<0.001$ & 16.40 & $<0.001$ \\
\hline $\begin{array}{l}\text { Fusarium species } \\
\text { Gatunki Fusarium }(3)\end{array}$ & 4 & 242.26 & $<0.001$ & 242.26 & $<0.001$ \\
\hline $1 \times 2$ & 6 & 73.89 & $<0.001$ & 79.67 & $<0.001$ \\
\hline $1 \times 3$ & 8 & 144.40 & $<0.001$ & 150.18 & $<0.001$ \\
\hline $2 \times 3$ & 12 & 23.76 & $<0.001$ & 29.54 & $<0.001$ \\
\hline
\end{tabular}


The calculated $\mathrm{Chi}^{2}$ statistics for the main effects and secondary interactions were significant, therefore the hypothesis of independence of the fungi frequency on the soil tillage system and plant cultivar should be rejected at $p<0.01$. The data presented in Table 3 facilitate the choice of statistical model that is optimal for the assessment of cultivar and tillage system effect on the frequency of fungi species investigated. The log-linear analysis has demonstrated significant differences between the tillage systems and wheat cultivars with respect to the frequency of the fungal species assessed. Significant interactions between cultivars and species of fungi, and between the tillage systems and species of fungi indicate variable degree of influence of the experimental factors on the abundance of pathogen populations. Significant interaction between the species frequency of pathogens and the tillage systems confirms considerable variation of the pathogens' frequency in conventional versus non ploughing tillage systems. On the other hand, interactions between the cultivars and fungal species mean that the cultivar factor itself had significantly affected the number of fungal isolates derived from the wheat grain, independently of the soil tillage system used.

Based on the results of the log-linear analysis presented in Tables 3, 4 we may conclude that winter wheat cultivars were characterized by higher frequency of Fusarium spp. under NP regimes of both types compared to Conv. tillage system. Moreover, the NP/c system contributed to insignificant increase in the density of fungal populations compared to NP/dh variant. In the NP/c variant the grain of 'Ostka Strzelecka' cv was infected to the greater extent compared to the remaining cultivars. In contrast, cv 'Kohelia' been showed an increased susceptibility to Fusarium infection when cultivated within the NP/dh tillage system. Results of the log-linear analysis (Tables 2,3 ) demonstrated that two species of Fusarium that predominated in the grain of winter wheat were $F$. avenaceum and $F$. poae, whereas the isolates of $F$. graminearum occurred at significantly lower a frequency, irrespectively of cultivar and tillage system variants. The structure of inter-dependency between the fungal frequencies and the experimental factors (cultivar and tillage system variants) was determined and described, using the correspondence analysis (CA). The graph, reflecting the reaction of cultivars on the experimental factors is represented in the two-dimentional coordinate system in such a way that the complete information on the varied influence of experimental factors on the population abundance of the investigated Fusarium species is maintained (Fig. 1).

Analysing the distribution of particular wheat cultivars in two-dimensional space, we may conclude that each cultivar differs significantly regarding variability of the examined fungi abundance in relation to tillage system.

This conclusion is supported by the relatively large distances - in the analysed biplot between cultivar in particular tillage variants. The exception is made by 'Muszelka', 'Satyna' and 'Kohelia' cultivar, but only in NP/dh tillage variant: close proximity of the points that reflects resistance of these cultivars in the biplot indicates that 'Muszelka', 'Kohelia' and Satyna show comparable number of Fusarium isolates in the NP/dh tillage regime. The vectors of $F$. poae and $F$. tricinctum are directed at $90^{\circ}$ angle to one another, which means 
that there is no correlation between their frequencies on the wheat kernels under variable soil tillage systems. On the contrary, the obtuse angle between $F$. graminearum and $F$. tricinctum vectors implies negative relationship between these species with respect to their frequencies on wheat kernels in the different tillage systems. The variable vector directions of $F$. poae, $F$. graminearum and F. tricinctum evidence that frequencies of the species of fungi in question varied considerably between the analysed soil tillage variants. Right-angle projections of the points representing cultivars within their respective tillage systems, onto the vectors representing fungi, confirm higher frequencies of $F$. poae on kernels of 'Ostka Strzelecka' cv. in NP/dh regime, and on the grain of 'Kohelia' cv. in NP/c system (Fig. 1). Likewise, the proximity of the points representing 'Muszelka' and 'Ostka Strzelecka' cvs under the NP/c regime, within the range of $F$. graminearum vector, proves the increased number of isolates of this species on the grain of both cultivars.

Table 4. Marginal frequencies of Fusarium in the grain of wheat in relation to tillage systems and cultivars. Means of 2012-2014

Tabela 4. Liczebność gatunków Fusarium spp. w zależności od systemu uprawy i odmiany. Średnie z lat 2012-2014

\begin{tabular}{|c|c|c|c|c|c|}
\hline \multirow{3}{*}{$\begin{array}{l}\text { Fusarium species } \\
\text { Gatunki Fusarium }\end{array}$} & \multicolumn{5}{|c|}{ Conventional tillage - Uprawa tradycyjna (Conv.) } \\
\hline & \multicolumn{4}{|c|}{ Cultivars - Odmiany } & \multirow{2}{*}{$\begin{array}{l}\text { Sum } \\
\text { Suma }\end{array}$} \\
\hline & 'Muszelka' & $\begin{array}{c}\text { 'Ostka } \\
\text { Strzelecka' }\end{array}$ & 'Kohelia' & 'Satyna' & \\
\hline F. avenaceum & 96 & 48 & 48 & 120 & 312 \\
\hline F. culmorum & 24 & 18 & 42 & 72 & 156 \\
\hline F. graminearum & 48 & 12 & 6 & 6 & 72 \\
\hline F. poae & 120 & 42 & 96 & 24 & 282 \\
\hline F. tricinctum & 0 & 30 & 60 & 36 & 126 \\
\hline \multirow[t]{2}{*}{ Sum - Suma } & 288 & 150 & 252 & 258 & 948 \\
\hline & \multicolumn{5}{|c|}{$\begin{array}{c}\text { Reduced tillage - Uprawa uproszczona } \\
\text { (NP/dh) }\end{array}$} \\
\hline F. avenaceum & 78 & 54 & 144 & 108 & 384 \\
\hline F. culmorum & 42 & 12 & 60 & 54 & 168 \\
\hline F. graminearum & 60 & 6 & 24 & 24 & 114 \\
\hline F. poae & 48 & 72 & 78 & 54 & 252 \\
\hline F. tricinctum & 66 & 12 & 84 & 42 & 204 \\
\hline \multirow[t]{2}{*}{ Sum - Suma } & 294 & 156 & 390 & 282 & 1122 \\
\hline & \multicolumn{5}{|c|}{$\begin{array}{c}\text { Reduced tillage - Uprawa uproszczona } \\
(\mathrm{NP} / \mathrm{c})\end{array}$} \\
\hline F. avenaceum & 132 & 162 & 18 & 72 & 384 \\
\hline F. culmorum & 72 & 78 & 12 & 60 & 222 \\
\hline F. graminearum & 78 & 72 & 6 & 24 & 180 \\
\hline F. poae & 78 & 18 & 132 & 54 & 282 \\
\hline F. tricinctum & 24 & 18 & 30 & 72 & 144 \\
\hline Sum - Suma & 384 & 348 & 198 & 282 & 1212 \\
\hline $\begin{array}{l}\text { Total No. } \\
\text { Całkowita liczba }\end{array}$ & 966 & 654 & 840 & 822 & 3282 \\
\hline
\end{tabular}

For abbreviations see Table 1 - Oznaczenia patrz tab. 1. 


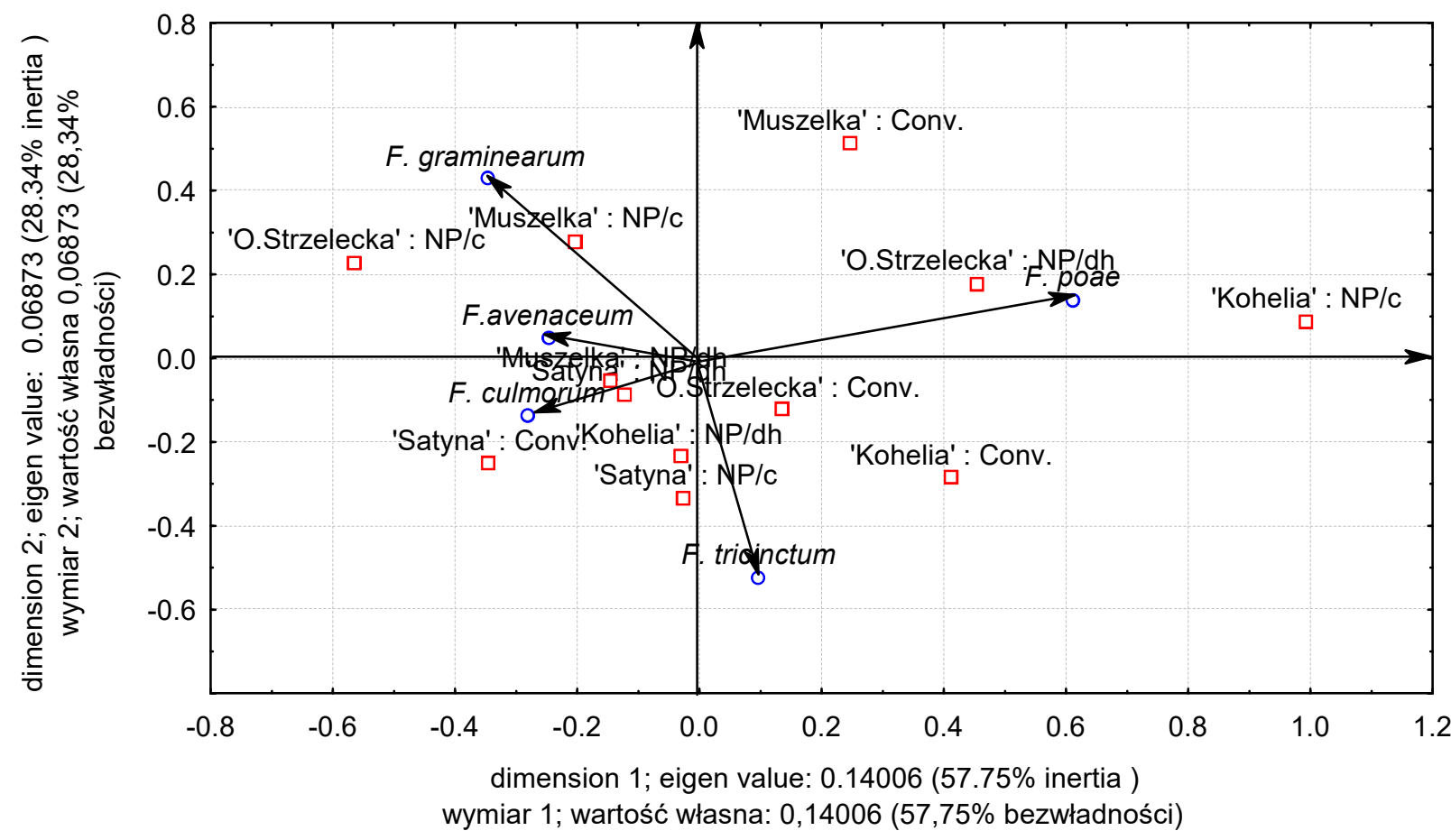

Fig. 1. Biplot - variability $(\mathrm{V} 1, \mathrm{~V} 2)$ of susceptibility of the wheat cultivars to Fusarium ssp. infection depending on the tillage systems

Ryc. 1. Biplot - zmienność (V1, V2) wrażliwości odmian pszenicy na grzyby z rodzaju Fusarium, w zależności od systemu uprawy

In the presented work, the grain of the winter wheat cvs was also characterized by chemical determination of mycotoxin content (ZEN, NIV and DON, see Table 5-7). Considerable variation was found between the years of the study with respect to the level of grain contamination with mycotoxins. In 2011 and 2013 no grain contamination was detected, whereas in 2012, precipitation at the start of the anthesis (BBCH 61-63) resulted in the delayed treatment with Alert 375 SE fungicide, appreciably reducing its efficacy in pathogen control.

Table 5. The content of nivalenol (NIV) in the grain $\left(\mathrm{mg}^{\cdot} \mathrm{kg}^{-1}\right), 2012$

Tabela 5. Zawartość niwalenolu w ziarnie $\left(\mathrm{w} \mathrm{mg} \cdot \mathrm{kg}^{-1}\right)$ w 2012 roku

\begin{tabular}{lcccc}
\hline $\begin{array}{c}\text { Cultivars } \\
\text { Odmiany }\end{array}$ & $\begin{array}{c}\text { Conventional tillage } \\
\text { Uprawa konwencjonalna } \\
\text { Conv. }\end{array}$ & $\begin{array}{c}\text { Reduced tillage } \\
\text { Uprawa uproszczona } \\
\text { NP/dh }\end{array}$ & $\begin{array}{c}\text { Reduced tillage } \\
\text { Uprawa uproszczona } \\
\text { NP/c }\end{array}$ & $\begin{array}{c}\text { Mean } \\
\text { Srednia }\end{array}$ \\
\hline 'Muszelka ' & 0.000 & 0.131 & 0.233 & 0.121 \\
\hline $\begin{array}{l}\text { 'Ostka } \\
\text { Strzelecka' }\end{array}$ & 0.000 & 0.145 & 0.182 & 0.109 \\
\hline 'Kohelia' & 0.000 & 0.465 & 1.424 & 0.630 \\
\hline 'Satyna' & 0.018 & 0.886 & 0.150 & 0.351 \\
\hline $\begin{array}{l}\text { Mean } \\
\text { Srednia }\end{array}$ & 0.005 & 0.407 & 0.497 & 0.303 \\
\hline
\end{tabular}

For abbreviations of soil tillage systems see Table 1 - Oznaczenia systemów uprawy gleby patrz tab. 1. 
Table 6. The content of deoxynivalenol (DON) in the grain $\left(\mathrm{mg} \cdot \mathrm{kg}^{-1}\right), 2012$

Tabela 6. Zawartość deoksyniwalenolu w ziarnie $\left(\mathrm{w} \mathrm{mg} \cdot \mathrm{kg}^{-1}\right)$ w 2012 roku

\begin{tabular}{lcccc}
\hline $\begin{array}{c}\text { Cultivars } \\
\text { Odmiany }\end{array}$ & $\begin{array}{c}\text { Conventional tillage } \\
\text { Uprawa konwencjonalna } \\
\text { Conv. }\end{array}$ & $\begin{array}{c}\text { Reduced tillage } \\
\text { Uprawa uproszczona } \\
\text { NP/dh }\end{array}$ & $\begin{array}{c}\text { Reduced tillage } \\
\text { Uprawa uproszczona } \\
\text { NP/c }\end{array}$ & $\begin{array}{c}\text { Mean } \\
\text { Srednia }\end{array}$ \\
\hline 'Muszelka' & 0.008 & 0.458 & 0.224 & 0.230 \\
\hline $\begin{array}{l}\text { 'Ostka } \\
\text { Strzelecka' }\end{array}$ & 0.006 & 0.325 & 0.368 & 0.233 \\
\hline 'Kohelia' & 0.000 & 0.420 & 1.012 & 0.477 \\
\hline 'Satyna' & 0.009 & 1.040 & 0.295 & 0.448 \\
\hline $\begin{array}{l}\text { Mean } \\
\text { Średnia }\end{array}$ & 0.006 & 0.561 & 0.475 & 0.347 \\
\hline
\end{tabular}

For abbreviations of soil tillage systems see Table 1 - Oznaczenia systemów uprawy gleby patrz tab. 1.

Table 7. The content of zearalenon (ZEN) in the grain $\left(\mathrm{mg} \cdot \mathrm{kg}^{-1}\right), 2012$

Tabela 7. Zawartość zearalenonu w ziarnie $\left(\mathrm{w} \mathrm{mg} \cdot \mathrm{kg}^{-1}\right) 2012$ roku

\begin{tabular}{lcccc}
\hline $\begin{array}{c}\text { Cultivars } \\
\text { Odmiany }\end{array}$ & $\begin{array}{c}\text { Conventional tillage } \\
\text { Uprawa konwencjonalna } \\
\text { Conv. }\end{array}$ & $\begin{array}{c}\text { Reduced tillage } \\
\text { Uprawa uproszczona } \\
\text { NP/dh }\end{array}$ & $\begin{array}{c}\text { Reduced tillage } \\
\text { Uprawa uproszczona } \\
\text { NP/c }\end{array}$ & $\begin{array}{c}\text { Mean } \\
\text { Średnia }\end{array}$ \\
\hline 'Muszelka' & 0.020 & 0.124 & 0.224 & 0.123 \\
\hline $\begin{array}{l}\text { 'Ostka } \\
\text { Strzelecka' }\end{array}$ & 0.000 & 0.032 & 0.024 & 0,019 \\
\hline 'Kohelia' & 0.010 & 0.352 & 0.923 & 0.428 \\
\hline 'Satyna' & 0.000 & 0.360 & 0.015 & 0.125 \\
\hline $\begin{array}{l}\text { Mean } \\
\text { Średnia }\end{array}$ & 0.008 & 0.217 & 0.297 & 0.174 \\
\hline
\end{tabular}

For abbreviations of soil tillage systems see Table 1 - Oznaczenia systemów uprawy gleby patrz tab. 1.

\section{DISCUSSION}

The maximum levels of mycotoxin concentration in the non-processed grain, set by the EU are $1.25 \mathrm{mg} \cdot \mathrm{kg}^{-1}$ for DON and $0,1 \mathrm{mg} \cdot \mathrm{kg}^{-1}$ for ZEN (Commission Regulation (EC) No. 1126/2007) In the present study, the grain of the observed cultivars grown within Conv. tillage system contained no important quantity of the respective mycotoxins.

On the contrary, under the NP regimes, despite of the one-year interim period in cereal cultures, the mycotoxin concentrations exceeded the current maximum levels set by the EU for ZEN and was close to maximum level for DON in some cultivars. Within the NP/dh system, the grain of Satyna cV was found to be highly contaminated with DON. Significant concentration of this mycotoxin was also detected in the grain of 'Kohelia' cv coming from the plots tilled with cultivator (NP/c). The analyses of ZEN content in the grain harvested from the NP regime plots had revealed concentrations of the toxin several times beyond the the maximum limits, and this was particularly true for the cultivars 'Kohelia' and 'Satyna'. On the contrary, cultivars: 'Muszelka' and 'Ostka Strzelecka' were characterized by lower degree of grain contamination with mycotoxins. The absence of a strict relationship between the frequency of Fusarium pathogens in grain and the degree of its contamination with mycotoxins may result from the variable pathogenicity of particular genotypes present within the analysed pathogen population. Considerable variation of the weather conditions between the study years makes any precision forecasting of the grain contamination with mycotoxins impossible. 
More precise projections can only be achieved for 15 to 30-day intervals that precede head infection (Xu et al. 2013). It has been stressed in majority of published papers that the non-ploughing systems may enhance the incidence of Fusarium pathogens in wheat cultures. Steinkellner and Langer (2004) had found that increasing of the depth of soil tillage treatments is accompanied by the gradual decrease of the number of isolates of Fusarium spp. found. Furthermore, a work accomplished in Germany proves that the non-ploughing tillage increases the content of DON in the grain of wheat, irrespectively of the type of forecrop used (Bartels and Rodeman 2003). Ploughing tillage, as compared to non-ploughing system, may reduce infection of wheat by $F$. graminearum by $90 \%$, even though it is carried out (and the wheat is grown) after the forecrop that is particularly risky for wheat e.g. maize (Miedaner 2012). Research from Poland also indicates an increase in Fusarium frequency under the regimes of shallow, superficial soil tillage. Using post-harvest, combined tillage unit seems to favor Fusarium infections of the stem base of wheat to the greatest extent, compared to the application of disc harrow or ploughing (Małecka et al. 2007).

When investigating different soil tillage variants, Dill-Macky and Jones (2000) found the highest level of head infections after direct planting, and in particular after cereal forecrops. DON content in the grain of wheat from the zero tillage variant was notably higher after maize forecrop compared to the winter wheat - winter wheat rotation link (Dill-Macky and Jones 2000). Research carried out in Lower Saxony region had demonstrated that the maize forecrop used within the non-ploughing tillage system may increase 3-fold DON concentration in wheat grain compared to conventional tillage (Lege et al. 2011). A lower level of wheat grain contamination, although still significantly higher in non-ploughing tillage systems, was reported from the rotations in which wheat was grown after sugar beet or cereal forecrop. On the other hand, the forecrop of winter oilseed rape reduces the risk of wheat grain contamination to the considerable extent, irrespectively of the soil tillage system (Lege et al. 2011). Considerable genetic variation of the analysed species, as well as the ongoing climatic changes favor the dispersal of the fungal pathogens, particularly in Southern Poland (Tóth et al. 2004; Pancalidi et al. 2010; Talas et al. 2011). It should be also stressed that the grain infection by Fusarium pathogens is the phenomenon affecting all parts of the kernel and not only its outer surface. At an early head infection, the pahogenic mycelium penetrates the aleurone layer and the endosperm of the kernel.

Unfortunately, the action of the fungicide products used as seed treatments is, in majority of the cases, restricted to the topmost layers of the kernel (Kiecana 2012). Fungicides in use against the pathogens of the genus Fusarium are characterized by a mediocre efficacy. The fungicide treatment to the crop should be applied at the beginning of anthesis (BBCH 61-63). Regrettably, farmers have only one or two days to attain full efficacy of the applied chemical. In practice, the efficacy of the fungicides controlling FHB is low because of the inappropriate application timing (Weber and Kita 2014).

Hence, only the relevant assessment of the grain contamination with mycotoxins, carried out in grain procurement stations, may effectively reduce the risk of consumption of the contaminated food. No unequivocal dependencies between the concentration of mycotoxins in grain and tillage systems, as well as chemical protection of plants, were noted in other research (Horoszkiewicz-Janka et al. 2016). The research has shown, that correlation 
coefficients between the damage levels of grain and the presence of mycotoxins can be low (Góral et al. 2012). Different cultivars can present high tolerance towards mycotoxin presence while showing low grain-damage levels. However, different genotypes can present low presence of DON in grain, despite high infection rates of grain (Góral et al. 2012).

\section{CONCLUSIONS}

1. In the conventional system the grain of the investigated cultivars showed very low mycotoxin content. Conversely, cultivar 'Satyna' showed increased DON content in grain collected from no-tillage system with only disc harrow use. Cultivar 'Kohelia' was characterized by increased grain contamination by DON for the grain obtained from no-tillage system with only cultivator use. Under reduced systems and despite of the one-year interim period in cereal cultures, the mycotoxin concentrations (NIV and ZEN) had amply exceeded the current maximum levels set by the EU.

2. The analyses of ZEN content in the grain harvested from the reduced systems regime plots had revealed concentrations of the compound several times beyond the maximum limits set for crops, and this was particularly true for the cultivars 'Kohelia' and 'Satyna'. On the contrary, cultivars: 'Muszelka' and 'Ostka Strzelecka' were characterized by lower degree of grain contamination with mycotoxins.

\section{REFERENCES}

Baert K., De Meulenaer B., Kamala A., Kasase C., Devlieghere F. 2006. Occurrence of patulin in organic, conventional, and handcrafted apple juices marketed in Belgium. J. Food Protec. 69, 1371-1378.

Bartels G., Rodeman B. 2003. Strategien zur Vermeidung von Mykotoxinen im Getreide. Gesunde Pflanzen 55(5), 125-135.

Booth C. 1971.The genus Fusarium. Kew, CMI, 179-182.

Buerstmayr H., Lemmens M., Hartl L., Doldi L., Steiner B., Stierschneider M., Ruckenbauer P. 2002. Molecular mapping of QTLs for Fusarium head blight resistance in spring wheat. I. Resistance to fungal spread (Type II resistance). Theor. Appl. Genet. 104, 84-91.

Buerstmayr H., Ban T., Anderson J.A. 2009. QTL mapping and marker-assisted selection for Fusarium head blight resistance in wheat: A review. Plant Breed. 128, 1-26.

Commission Regulation (EC) No. 1126/2007 of 28 September 2007 amending Regulation (EC) No. 1881/2006 setting maximum levels for certain contaminants in foodstuffs as regards Fusarium toxins in maize and maize products, www.fao.org/faolex/results/details/en/c/LEX-FAOC073818, access: September 2016.

Dill-Macky R., Jones R.K. 2000.The effect of previous crop residues and tillage on Fusarium head blight of wheat. Plant Dis. 84, 71-76.

Goliński P., Kiecana I., Kaczmarek Z., Kostecki M., Kaptur P., Wisniewska H., Chełkowski J. 1999. Scab response of selected winter what cultivars after inoculation with Fusarium avenaceum (Fr.) Sacc. J. Phytopathol 147, 717-723.

Goodman H. 1971. The analysis of multidimensional contingency tables: Stepwise procedures and direct estimation methods for models building for multiple classification. Technometrics 13, 33-61.

Góral T. 2006. Odporność odmian pszenicy na fuzariozę kłosów powodowaną przez Fusarium culmorum (W.G. Smith) Sacc. [Resistance of wheat cultivars to Fusarium head blight caused by Fusarium culmorum (W.G. Smith) Sacc.]. Biul. IHAR 242, 63-78. [in Polish] 
Góral T. 2005. Źródła odporności pszenicy na fuzariozę kłosów powodowaną przez Fusarium culmorum (W.G. Smith) Sacc. [Sources of wheat resistance to Fusarium head blight caused by Fusarium culmorum (W.G. Smith) Sacc.]. Biul. IHAR 235, 115-132. [in Polish]

Góral T., Ochodzki P., Bulinska-Radomska Z. 2012. Odporność na fuzariozę kłosów powodowaną przez Fusarium culmorum i zawartość mikotoksyn fuzaryjnych w ziarnie gatunków zbóż jarych przeznaczonych do upraw ekologicznych [Resistance to Fusarium head blight caused by Fusarium culmorum and Fusarium mycotoxins content in grain of spring cereal species intended for organic farming]. Biul. IHAR 263, 43-53. [in Polish]

Horoszkiewicz-Janka J., Jajor E., Pieczul K. 2016. Wpływ systemu uprawy i przedplonu na zasiedlenie ziarna przez grzyby z rodzaju Fusarium i zawartość mikotoksyn w ziarnie pszenicy jarej [Influence of cultivation system and forecrop on colonization by fungi of the genus Fusarium and mycotoxin kontent in grain of spring wheat]. Prog. Plant Prot./Post. Ochr. Rośl. 56(1), 12-18. [in Polish]

Kiecana I. 2012. Szkodliwość wybranych gatunków grzybów dla zbóż z uwzględnieniem ich właściwości toksynotwórczych, w: Patogeny roślinne problemem rolnictwa i przetwórstwa. Warsztaty naukowe, Puławy 21.06. 2012. Puławy, IUNG PIB. [in Polish]

Lege A., Brandfass C., Weinert J. 2011. Schlagspezifisches Fusarium Risiko frühzeitig richtig einschätzen. LWK Niedersachsen, www.Iwk-niedersachsen.de/index, access: February 2012.

Lemmens M., Josephs R., Schumacher R., Grausgruber H., Buerstmayr H., Ruckenbauer P., Neuhold G., Fidesser M., Krska R.1997. Head blight (Fusarium spp.) on wheat: investigations on the relationship between disease symptoms and mycotoxin content. Cereal Res. Comm. 25, 459-465.

Małecka I., Sawińska Z., Blecharczyk A. 2007. Wpływ uprawy roli na występowanie chorób w pszenicy ozimej $\mathrm{i}$ jęczmieniu jarym [The effect of soil tillage on disease incidence in winter wheat and in spring barley]. Prog. Plant Prot./Post. Ochr. Rośl. 47(2), 189-192. [in Polish]

Miedaner T. 2012. Mykotoxine in Weizen und Mais. Frankfurt am Main, DLG Verlag, 3-84.

Nelson P.E., Toussoun T.A., Marasas W.F.O. 1983. Fusarium species: an illustrated manual for identification. Press. Prog. Plant Prot./Post. Ochr. Rośl. 37, 291-293.

Oliver R.E., Cai X., Friesen T.L., Halley S., Stack R.W., Xu S.S. 2008. Evaluation of Fusarium head blight resistance in tetraploid (Triticum turgidum L.). Crop. Sci. 48, 213-221.

Pancalidi D., Tonti S., Prodi A., Salomoni D., Dal Prà M., Nipoti P. 2010. Survey of the main causal agent of Fusarium head blight of durum wheat around Bologna, northern Italy. Phytopathol. Mediterr. 49, 258-266,

Perek A., Świerczyńska I. 2012. Wpływ fungicydów na antagonizm grzybów Trichoderma viride i Fusarium spp. w warunkach in vitro [Influence of fungicides on antagonism of fungi Trichoderma viride and Fusarium spp. under in vitro conditions]. Prog. Plant Prot./Post. Ochr. Rośl. 52(4), 1038-1041 [in Polish]

Rudd J.C., Horsley R.D., Mckendry A.L., Elias E.M. 2001. Host plant resistance genes for Fusarium head blight: Sources, mechanisms, and utility in conventional breeding systems. Crop Sci. 41, $620-627$,

Sadowski J., Gołębiowska H., Wysocki A. 2010. Metoda oznaczania mikotoksyn w ziarnie kukurydzy [Method for determination of mycotoxins in maize grain]. Prog. Plant Prot./Post. Ochr. Rośl. 50(4), 1963-1966. [in Polish]

Salas B., Steffenson B.J., Casper H.H., Tacke B., Prom L.K., Fetch T.G., Schwarz P.B. 1999. Fusarium species pathogenic to barley and their associated mycotoxins. Plant Dis. 83, 667-674.

Srinivasachary-Gosman N., Steed A., Hollins T.W., Bayles R., Jennings P. 2009. Semi-dwarfing Rht-B1 and Rht-D1 loci of wheat differ significantly in their influence on resistance to Fusarium head blight. Theor. Appl. Genet. 118, 695-702.

Steinkellner S., Langer I. 2004. Impact of tillage on the incidence of Fusarium spp. in soil. Plant Soil. 267(1-2), 13-22. 
Suproniene S., Mankevićiené A., Kadźiené G., Kaćergius A., Feiza V., Feiziené D., Semaśkiené R., Dabkevicius Z., Tamośiûnas K. 2012. The impact of tillage and fertilization on fusarium infection and mycotoxin production in wheat grains. Zemdirbyste-Agriculture 99(3), 265-272.

Talas E. Parzies H.K., Miedaner T. 2011. Diversity in genetic structure and chemotype composition of Fusarium graminearum sensu stricto populations causing wheat head blight in individual fiels in Germany. Eur. J. Plant Pathol. 131, 39-48.

Tóth B., Mesterházy A., Nicholson P., Teren J., Varga J. 2004. Mycotoxin production and molecular variability of European and American isolates of Fusarium culmorum. Eur. J. Plant Pathol. 110, 587-599.

Weber R., Kita W. 2010. Effects of tillage system and forecrop type on frequency of Fusarium culmorum and $F$. avenaceum occurrence on culm base of some winter wheat (Triticum aestivum L.) cultivars. Acta Agrobot. 63(1),121-128.

Weber R., Kita W. 2014. Zagrożenia i sposoby ograniczania chorób fuzaryjnych i mikotoksyn w zbożach i kukurydzy [Risik and methods to reduce Fusarium disease and mycotoxin kontent in small grains and maize cultures]. Monogr. Rozpr. Nauk. IUNG-PIB Puławy 43, 7-98. [in Polish]

Xu X., Madden L.V., Edwards S.G., Doohan F.M., Moretti A., Hornok L., Nicholson P., Ritieni A. 2013. Developing logistic models to relate the accumulation of DON associated with Fusarium head blight to climatic conditions in Europe. Eur. J. Plant Pathol. 137(4), 689-706.

\begin{abstract}
The aim of the present work was to analyse the variability of the incidence of Fusarium species and mycotoxins in the grain of wheat, depending on wheat cultivar and soil tillage system. The experimental factors included: 1 . Soil tillage system: conventional system (Conv.), two non-ploughing (NP) systems, one of them using disc harrow (NP/dh), the other one using cultivator (NP/c); 2. Winter wheat cultivars ('Muszelka', 'Ostka Strzelecka', 'Kohelia' and 'Satyna'). The grain of the winter wheat cultivars tested was more susceptible to Fusarium infections under both NP tillage systems, compared to Conv. tillage system. In the Conv. system the grain of the investigated cultivars had shown very low mycotoxin content. In contrast, under NP systems and despite of the one-year interim period in cereal cultures, the zearalenon concentrations had amply exceeded the current maximum levels set by the EU. Within the NP/dh system, the grain of 'Satyna' cultivar was found to be highly contaminated with deoxynivalenol. Significant concentration of this mycotoxin was also detected in the grain of 'Kohelia' cultivar coming from the plots tilled with cultivator (NP/c). The analyses of zearalenone content in the grain harvested from the NP regime plots had revealed concentrations of the compound several times beyond the maximum limits set for crops, and this was particularly true for the cultivars 'Kohelia' and 'Satyna'. On the contrary, cultivars: 'Muszelka' and 'Ostka Strzelecka' were characterized by lower degree of grain contamination with mycotoxins.
\end{abstract}


